\title{
Obesity Treatment Can Also Cure Type 2 Diabetes Mellitus: A Case Report
}

\author{
Tip 2 Diabetes Mellitusu Olan Obezite Hastasında Obezite Tedavisi Diyabetide Tedavi \\ Edebilir: Bir Olgu Örneği
}

(D) Feray Akbaș, (D) Hanife Usta Atmaca

University of Health Sciences Turkey, İstanbul Training and Research Hospital, Clinic of Internal Medicine, İstanbul, Turkey

\begin{abstract}
Obesity is a leading risk factor for type 2 diabetes mellitus (DM). Lifestyle modification should be the first step of diabetes treatment regardless of the medications prescribed upon diagnosis. An obese patient who was diagnosed with type 2 DM during visit at his obesity outpatient clinic was prescribed medication and lifestyle modification. The patient achieved remission of diabetes after losing $25 \%$ of weight during the follow-up period. This case emphasises the importance of lifestyle modification in diabetes treatment.
\end{abstract}

Keywords: Obesity, type 2 diabetes mellitus, lifestyle modification

\section{öZ}

Obezite, tip 2 diabetes mellitus (DM) için önde gelen risk faktörüdür. Tanı konduğunda hastaya önerilen medikal diyabet tedavisi ne olursa olsun, yașam tarzı değişikliği tedavinin birinci basamağını oluşturmalıdır. Burada; obezite polikliniğine başvurusunda tip 2 DM tanısı konan, yaşam tarzı değișikliği ve ilaç tedavisi bașlanıp \%25 kilo kaybı sonrasında ilaçsız izlemde diyabet kliniği bulunmayan bir olgu ele alınarak, diyabet tedavisinde yaşam tarzı değişikliğinin öneminin bir kez daha vurgulanması amaçlanmıştır.

Anahtar Kelimeler: Obezite, tip 2 diabetes mellitus, yașam tarzı değișikliği

\section{Introduction}

Obesity is the leading risk factor for type 2 diabetes mellitus (DM). Regardless of the medical diabetes treatment suggested to the patient when diagnosed, lifestyle change should be the first step of treatment. In this study, it is aimed to emphasize once again the importance of lifestyle change in the treatment of diabetes by addressing a case who was diagnosed with type 2 DM at the admission to the obesity outpatient clinic, who did not have a diabetes clinic in drug-free follow-up after a $25 \%$ weight loss with lifestyle change and medication.

\section{Case Report}

A 34-year-old male patient applied to the obesity outpatient clinic for the first time in February 2016. The patient was a high school graduate, working in the textile industry, and was married. His childhood weight was normal; she started to gain weight after marriage and reached his highest weight in the last 5 years. He applied to our outpatient clinic because he was at the highest weight in his life and started to have difficulty in movements. His medical history was unremarkable except for tonsillectomy operation. He did not have a diagnosis or a history of drug use that could cause weight gain. He had never attempted to lose weight before. In his family history, there was obesity and type 2 DM in the mother. He did not smoke or drink alcohol.

Eating habits: He ate 3 main meals a day, but his biggest meal was dinner. He continued to eat every night at home until he fell asleep, and during daylight hours at work, between meals, and these were usually simple carbohydrates (such as wafers, sweets, cakes, biscuits). There were no signs of eating disorders.

Physical activity habits: He was not doing exercises. He was using public transport on his way to work and walked between transport points and home/work 
Psychological status: There were no signs of depression or mood disorder.

Motivational status: The patient wanted to voluntarily participate in a weight loss program and lose weight only for his health, he was motivated.

Physical examination: Height: $174 \mathrm{~cm}$, weight: $112 \mathrm{~kg}$, body mass index (BMI): $37 \mathrm{~kg} / \mathrm{m}^{2}$, waist circumference: $116 \mathrm{~cm}$, hip circumference: 120 $\mathrm{cm}$. Other physical examination findings were normal except arterial blood pressure with $140 / 100 \mathrm{mmHg}$.

Hemogram, routine biochemistry, hemoglobinA1c (HbA1c), $2^{\text {nd }}$ hour postprandial blood glucose, hormone profile, then $1 \mathrm{mg}$ dexamethasone suppression test, spot urine protein/creatinine were checked, electrocardiography, echocardiography, 24-hour ambulatory blood pressure monitoring and abdominal ultrasonography were performed.

After the results were evaluated, he was diagnosed with type 2 DM, hypertension $(\mathrm{HT})$ and hyperlipidemia $(\mathrm{HL})$ according to current guidelines (1-3). Drug treatment was started with metformin and olmesartan/thiazide. The patient refused to receive $\mathrm{HL}$ therapy. Simultaneously, the patient was given medical nutrition therapy, exercise prescription, and training for behavior change.

Patient made great adjustment to recommendations and came to the doctor and dietician controls regularly. He dropped from $112 \mathrm{~kg}$ to $84 \mathrm{~kg}$, giving a total of $28 \mathrm{~kg}$ in the 3-year follow-up. When he had $2^{\text {nd }}$ degree obesity, BMI decreased to $28 \mathrm{~kg} / \mathrm{m}^{2}$ and this switched him to overweight group (Table 1). HbA1c was 6.2 in May 2016 and was 5.4 in November 2016, and blood pressure was low. Drug treatments were gradually discontinued when the patient was being monitored. With continued lifestyle change, there was no increase in blood sugar (BS), A1C and blood pressure (Table 2). Scheduled last application date: July 2019 and the patient is still in the control program.

Informed consent was obtained from the patient.

\section{Discussion}

Obesity is the main determinant of poor metabolic control in type 2 diabetes. Therefore, prevention and treatment of obesity is of great importance in the management of patients with type 2 diabetes. (4)

5-10\% weight loss can lower HbA1c levels, improve cardiovascular risk factors, reduce the use of antihyperglycemic, antihypertensive and lipidlowering drugs within 1 year, and bring type 2 diabetes into remission within the first 5 years $(5,6)$.
Table 2. Metabolic changes

\begin{tabular}{|l|l|l|}
\hline Parameter & First application & Last control \\
\hline FBS (mg/dL) & 126 & 79 \\
\hline HbA1c (\%) & 7.5 & 5.2 \\
\hline TG $(\mathrm{mg} / \mathrm{dL})$ & 208 & 67 \\
\hline LDL $(\mathrm{mg} / \mathrm{dL})$ & 136 & 92 \\
\hline HDL $(\mathrm{mg} / \mathrm{dL})$ & 31 & 47 \\
\hline Insulin (iu/mL) & 43.93 & 4.33 \\
\hline GGT $(\mathrm{mg} / \mathrm{dL})$ & 59 & 33 \\
\hline
\end{tabular}

FBS: Fasting blood sugar, HbA1c: hemoglobinA1c, TG: triglyceride, LDL: low-density lipoprotein, HDL: high-density lipoprotein, GGT: gamma-glutamyl transferase

Many studies have shown that the combination of energy-restricted diets and exercise has an additive effect on weight loss. The beneficial metabolic effects of the Mediterranean diet have been identified and may delay the need for antihyperglycemic drug therapy in newly diagnosed type 2 diabetes patients $(5,6)$.

In our patient, after weight loss, the amount of medication used for diabetes and HT was first reduced and then stopped without the need for medication. BS and blood pressure arterial values were normal in follow-up without medication; diabetes and HT went into remission with the continuation of lifestyle changes.

Medical nutrition therapy, physical activity and behavior change constitute the basis of obesity treatment. The first step of type 2 DM treatment is to make these changes and to provide weight loss in patients with obesity/overweight. Permanent lifestyle change is the greatest success in both diabetes and obesity treatment.

\section{Ethics}

Informed Consent: Informed consent was obtained from the patient.

Peer-review: Externally peer-reviewed.

Authorship Contributions: Surgical and Medical Practices - F.A.; Concept - F.A.; Design - F.A.; Data Collection or Processing - F.A., H.U.A.; Analysis or Interpretation - F.A., H.U.A.; Literature Search - F.A., H.U.A.; Writing F.A., H.U.A.

Conflict of Interest: No conflict of interest was declared by the authors

Financial Disclosure: The authors declared that this study received no financial support.

Table 1. Weight controls of the patient

\begin{tabular}{|c|c|c|c|c|c|c|c|c|}
\hline Date & 02.2016 & 05.2016 & 8.2016 & 11.2016 & 01.2017 & 02.2017 & 04.2017 & 06.2017 \\
\hline Weight (kg) & 112 & 96 & 91 & 88 & 90 & 90 & 91 & 91 \\
\hline Date & 07.2017 & 10.2017 & 12.2017 & 02.2018 & 05.2018 & 8.2018 & 01.2019 & 07.2019 \\
\hline Weight (kg) & 90 & 94 & 86 & 82 & 82 & 85 & 84 & 84 \\
\hline
\end{tabular}




\section{References}

1. Expert Committee on the Diagnosis and Classification of Diabetes Mellitus. Report of the Expert Committee on the Diagnosis and Classification of Diabetes Mellitus. Diabetes Care 1997; 20: 1183-97.

2. Williams B, Mancia G, Spiering W, Rosei EA, Azizi M, Burnier M, et al. 2018 ESC/ESH Guidelines for the management of arterial hypertension: The Task Force for the management of arterial hypertension of the European Society of Cardiology (ESC) and the European Society of Hypertension (ESH). Eur Heart J 2018; 39: 3021-104.

3. Jellinger PS, Smith DA, Mehta AE, Ganda O, Handelsman Y, Rodbard HW, et al. American Association of Clinical Endocrinologists' Guidelines for Management of Dyslipidemia and Prevention of Atherosclerosis: executive summary. Endocr Pract 2012; 18: 269-93.
4. Sonmez A, Yumuk V, Haymana C, Demirci I, Barcin C, KıyıCI S, et al. Impact of Obesity on the Metabolic Control of Type 2 Diabetes: Results of the Turkish Nationwide Survey of Glycemic and Other Metabolic Parameters of Patients with Diabetes Mellitus (TEMD Obesity Study). Obes Facts 2019; 12: 167-78.

5. Leitner DR, Frühbeck G, Yumuk V, Schindler K, Micic D, Woodward E, et al. Obesity and Type 2 Diabetes: Two Diseases with a Need for Combined Treatment Strategies - EASO Can Lead the Way. Obes Facts 2017; 10: 483-92.

6. Dambha-Miller H, Day AJ, Strelitz J, Irving G, Griffin SJ. Behaviour change, weight loss and remission of Type 2 diabetes: a community-based prospective cohort study. Diabet Med 2020; 37: 681-8. 